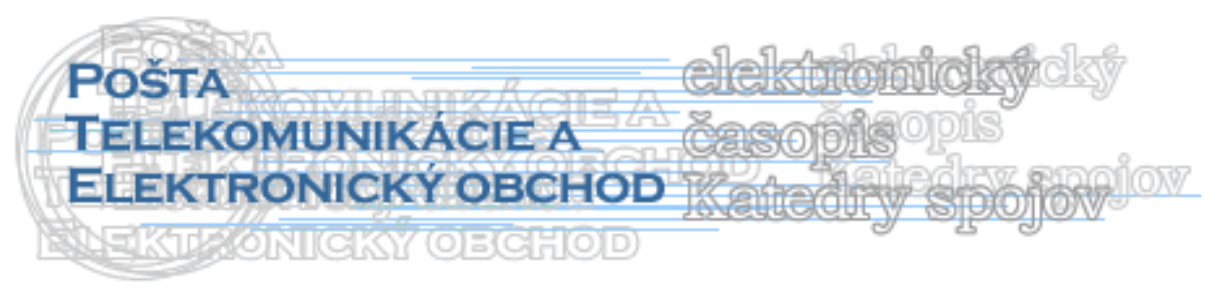

\title{
POSTUP PLÁNOVANIA KVALITY POŠTOVÝCH SLUŽIEB PODLA JURANOVEJ METODIKY
}

\author{
Stanislava Valovičová*
}

\section{Úvod}

Plánovanie kvality je popri riadení kvality a zlepšovaní kvality jedným zo základných procesov tzv. Juranovej trilógie kvality. Obsah pojmu plánovanie kvality Juran stručne charakterizoval ako proces formovania ciel'ov kvality a vývoja prostriedkov pre splnenie týchto ciel'ov. Výsledkom plánovania kvality, ako procesu formovania ciel'ov a prípravy $\mathrm{k}$ ich dosiahnutiu, by mal byt' postup vhodný k dosiahnutiu ciel'ov.

Príspevok je zameraný na hl'adanie spôsobu aplikovania metodického postupu plánovania kvality výrobkov podl’a M. J. Jurana v oblasti poštových služieb.

\section{Joseph M. Juran - významná osobnost' v oblasti manažérstva kvality}

V oblasti manažérstva kvality významne prispelo niekol'ko priekopníkov. V úvode stručne popisujeme prínos Jurana s ciel'om ukázat' vplyv teórií, ktoré boli revolučné v 50-tych rokoch, na súčasný stav a na znovu objavené aspekty moderného manažérstva kvality.

Juran bol súčasníkom W. E. Deminga, ktorý sa všeobecne považuje za jedného zo zakladatel'ov moderného manažérstva kvality. J. M Juran sa zaoberal organizáciou výroby v podniku a riadením práce l'udí. V Japonsku aplikoval systém zásobovania „JIT“, ktorý bol vyvinutý pre potreby výrobných programov v USA počas druhej svetovej vojny. Metóda je zameraná na minimalizáciu vel'kých zásob, pričom sa znižujú nielen náklady na zásoby, ale zároveň sa zvyšuje produktivita práce a kvalita výrobku.

Juran taktiež navrhol vo svojej známej príručke kl’učcovú definíciu kvality: kvalita je vhodnost' na použitie. Zákazník je podl'a takejto definície v centre dôležitosti pri manažérstve kvality. Juran bol známou osobnost'ou. Jeho názorom bolo, že prvoradá zodpovednost' za manažérstvo kvality je na vrcholovom manažmente organizácie. Vrcholový manažment, v časoch Jurana to bol starší manažment, mal zaručovat', že plánovanie kvality, riadenie kvality a zlepšovanie kvality sa formuje s trendom trhu.

Jurana a Deminga poslali $\mathrm{v}$ roku 1950 do Japonska s úmyslom rekonštruovat' priemysel tejto krajiny. Bola to iniciatíva USA po druhej svetovej vojne. Japonsko venovalo vel'kú pozornost' ich metódam a ich kurzy boli mimoriadne úspešné. Japonsko nezaviedlo nič, čo by nebolo v súlade s ich teóriami. Vykonávali a prakticky realizovali teoretické koncepcie, na druhej strane americké firmy venovali len okrajovú pozornost' teóriám Deminga a Jurana.

\footnotetext{
* Ing. Stanislava Valovičová, PhD., Katedra spojov, Fakulta prevádzky a ekonomiky dopravy a spojov, Žilinská univerzita, Univerzitná 1, 01026 Žilina, tel.: 041/513 3133, e-mail: Stanislava.Valovicova@fpedas.utc.sk
} 
Japonské výrobky boli považované za výrobky nízkej kvality. Systematickým používaním manažérstva kvality bol japonský priemysel schopný zvýšit' kvalitu svojich výrobkov tak vel'mi, že $\mathrm{v}$ mnohých prípadoch sa dostali $\mathrm{v}$ kvalite na vyššiu úroveň ako americké alebo európske výrobky. Tento výkon Japonska pochopitel'ne stimuloval záujem o manažérstvo kvality najmä v Amerike a západnej Európe. V 80-tych rokoch Američania znovu objavili teórie Deminga a Jurana, lebo tieto sa vel'mi zhodovali s vývojom kvality v americkom automobilovom priemysle.

\section{Postup plánovania kvality výrobkov}

Plánovanie kvality výrobkov je dôležitou súčast’ou plánovania kvality. Juran svoj postup plánovania kvality výrobkov charakterizoval ako postupnost' nasledujúcich desiatich činností:

- určenie zákazníkov,

- zistenie potrieb zákazníkov,

- preklad potrieb zákazníkov do reči výrobcu,

- stanovenie meratel'ných parametrov,

- zavedenie merania,

- vývoj výrobku,

- optimalizácia návrhu výrobku,

- vývoj procesu,

- optimalizácia a preukázanie spôsobilosti procesu,

- prevod do výrobných inštrukcií.

\section{Postup plánovania kvality poštových služieb podl’a metodiky J. M. Jurana}

Je samozrejmé, že známe systémové prístupy k manažérstvu kvality možno v oblasti poštových služieb aplikovat' len za predpokladu, že zvolené postupy prispôsobíme podmienkam, v ktorých sa poštový podnik uplatňujúci manažment kvality nachádza. Rešpektovaním uvedenej požiadavky by sme Juranov postup plánovania kvality výrobkov mohli transformovat' do takej podoby, ako je uvedená na obrázku č. 1. Na základe tejto štruktúry je v d'alšej stati príspevku podrobnejšie popísaná postupnost' jednotlivých činností.

Ciele kvality navrhovanej poštovej služby vyplývajú z potrieb zákazníka a zo strategických ciel'ov poštového podniku. Je dôležité poznat' potenciálnych zákazníkov a ich skutočné potreby. Za zákazníka sa odporúča považovat' každého, na koho produkt nejakým spôsobom pôsobí. Zákazníkov je vhodné segmentovat'. V prípade, ked' je potenciálnych zákazníkov vel'a, možno aplikovat' Paretovu analýzu, ktorá ul'ahčí ich rozdelenie na životne dôležitú menšinu a užitočnú väčšinu podl'a očakávaného objemu predaja.

Pri zist'ovaní potrieb zákazníkov je potrebné využit’ čo najširšie spektrum možných zdrojov informácií, napríklad interview so zákazníkmi, zasielanie dotazníkov, správy z prieskumu trhu, štúdie konkurencieschopnosti novej poštovej služby a pod. Pri špecifikácii požiadaviek sa odporúča sledovat' predovšetkým požiadavky životne dôležitej menšiny, ale treba rešpektovat' aj ostatných perspektívnych zákazníkov. Snaha vyhoviet' čo najväčšiemu počtu potenciálnych zákazníkov môže v niektorých prípadoch vyústit' do návrhu viacerých variant produktu.

Preklad potrieb zákazníka do reči poskytovatel’a poštovej služby spočíva v transformovaní zákazníckych potrieb do konkrétnych technických špecifikácii. V tomto kroku môže ako vhodný nástroj poslúžit' metodika QFD známa pod názvom Dom kvality. 

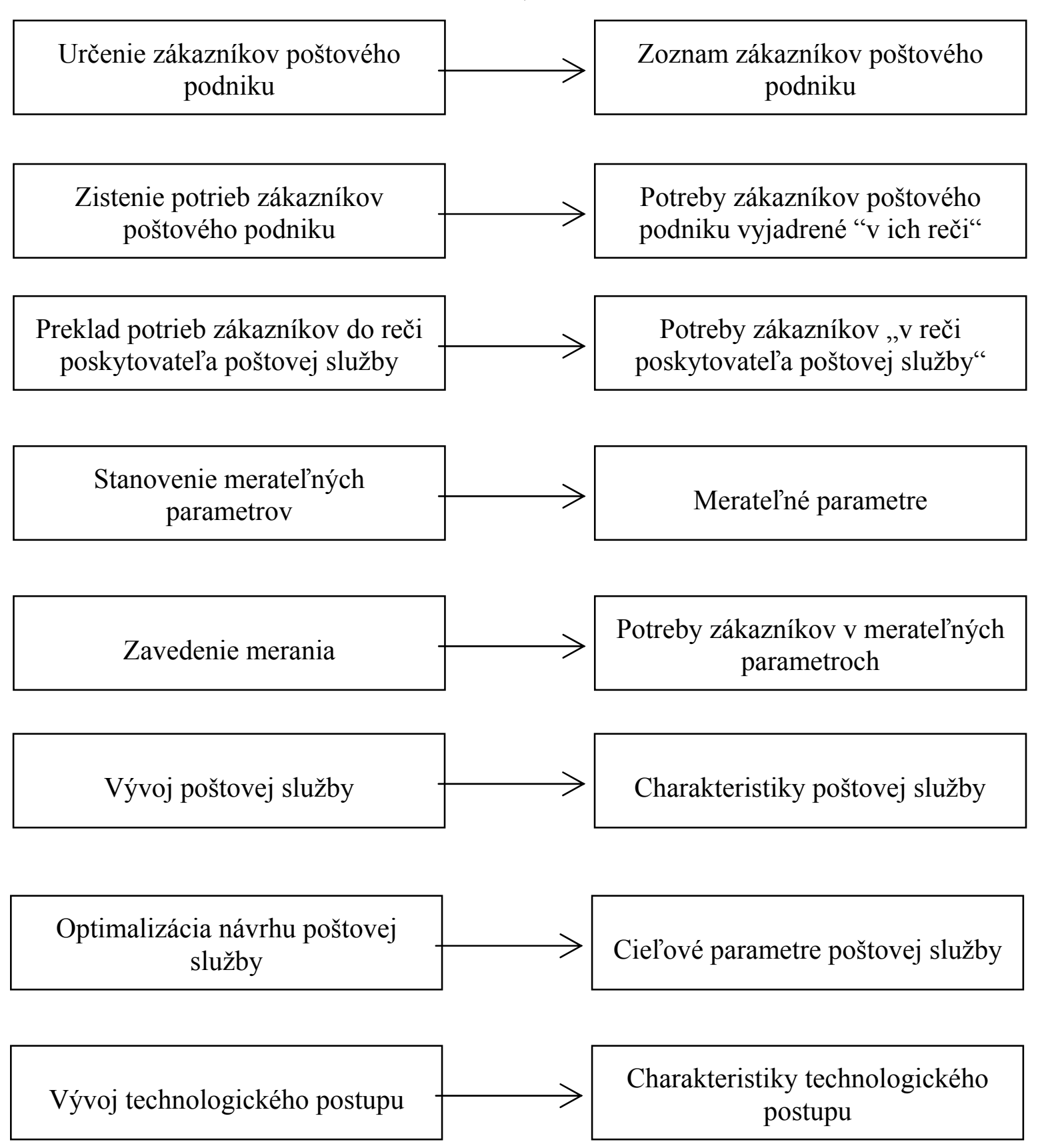

Optimalizácia a preukázanie spôsobilosti technologic. postupu

Technologický postup pripravený na prevod do prevádzkových inštrukcií

Prevod technologického postupu do prevádzkových inštrukcií

Technologický postup pripravený na poskytovanie poštovej služby

Obr. 1: Postup plánovania kvality poštových služieb podl’a koncepcie Josepha M. 
Pri stanovení meratel’ných parametrov sú najlepšie technické špecifikácie produktu charakterizované číselnými hodnotami meratel'ných parametrov. Pokial' sú potreby zákazníkov transformované do meratel'ných parametrov poštovej služby, musí byt' poskytovatel' služby schopný uskutočňovat' alebo zabezpečit' príslušné merania.

Slovenská pošta, a.s. zabezpečuje meranie spokojnosti svojich zákazníkov s kvalitou poštových služieb, ale aj meranie časov čakania na poštách a meranie spokojnosti svojich zamestnancov. Taktiež sa realizuje meranie kvality dopravy viacerých druhov poštových zásielok metódou „end to end“, pričom výsledky merania sú porovnávané s predpísanou lehotou pre včasnost' dopravy, ktorá je definovaná v národnej i európskej norme.

Pokial' ide o vývoj poštovej služby, treba stanovit' znaky kvality produktu zodpovedajúce požiadavkám zákazníka. Okrem požiadaviek zákazníkov je pri vývoji poštovej služby potrebné zohl'adňovat' aj niektoré d'alšie aspekty:

- strategické zámery poštového podniku,

- úroveň vedy, techniky a technológií v danej oblasti,

- informácie o potenciálnych zdrojoch a možnostiach poštového podniku,

- obmedzujúce faktory - napr.: platná legislatíva,

- imidž podniku resp. značky a pod.

Ďalej je potrebné venovat' pozornost' optimalizácii návrhu poštovej služby. $\mathrm{V}$ trhovom prostredí by znaky kvality navrhovaného produktu mali splńnat požiadavky zákazníkov a byt' konkurencieschopné. Za dôležité nástroje optimalizácie navrhovaného produktu sú považované Design Review t.j. preskúmanie návrhu, ktorého súčast'ou je FMEA návrhu produktu a metóda FTA.

Vývoj poštovej služby by mal prebiehat' za účasti technológov, resp. zástupcovia technológie by sa mali zúčastnit' hodnotenia jednotlivých fáz vývoja produktu. Neoddelitel'nou súčast'ou vývoja technologického postupu je aj vývoj jeho riadenia a plánovanie kontrolných miest, v ktorých budú sledované parametre procesu a zaistená spätná väzba.

V postupnosti činností nasleduje optimalizácia a preukázanie spôsobilosti technologického postupu. Optimalizácia návrhu procesu využíva podobné metódy ako optimalizácia návrhu produktu (Design Review, FMEA). Súčast'ou overovania vhodnosti technologického postupu by malo byt' hodnotenie jeho spôsobilosti, ktoré umožňuje posúdit' jeho schopnost' trvalo dosahovat' požadované hodnoty znakov kvality poštovej služby.

Záverečným krokom postupu, ktorý odporúča Juran je prevod procesu do výrobných inštrukcií. V našom prípade ide o prevod technologického postupu do prevádzkových inštrukcií. Spôsobilost' navrhnutého technologického postupu by mala byt' potvrdená v podmienkach poštovej prevádzky. Nevyhnutne potrebné je taktiež stanovit' príslušné prevádzkové inštrukcie.

\section{Záver}

Definovanie súčasného a ciel’ového profilu poštového podniku na základe poznania zákazníckych potrieb je východiskom aplikácie komplexného manažmentu kvality. Pre zlepšovatel'ov kvality poštových služieb musí byt' nesmierne dôležité, aby rozmýšl’ali v rámci 
celkovej tendencie, ktorá dáva iniciatíve zlepšovania smer a ktorá je doplnená vhodnou metodikou, nástrojmi a technikami zvyšovania kvality.

\section{Literatúra}

[1] ČOREJOVÁ, T. - ROSTÁŠOVÁ, M.: Diagnostický postup v manažérstve kvality v pošte. Žilina: EDIS- vydavatel'stvo ŽU, 1999. 94s. ISBN 80-7100-619-X

[2] PLURA, J.: Plánovaní a neustálé zlepšování jakosti. Praha: Computer Press, 2001. 244 s. ISBN 80-7226-543-1

[3] www.ueapme.com 